\title{
The Investigation of the Pharmacokinetics of Two Enrofloxacin Preparations Following Parenteral Administration in Calves
}

\author{
Gül Banu Çiçek Bideci \& Sezai Kaya
}

\begin{abstract}
Background: Enrofloxacin is a bactericidal antimicrobial drug in the fluoroquinolone group, developed for use only in the veterinary field. It is effective against gram negative and gram positive bacteria, Mikoplazma, Rickettsia, Ehrlichia ve Chlamydia. Enrofloxacin is converted to several effective and ineffective metabolites including ciprofloxacin. Ten to fifty percent of the drug is eliminated via urine and bile in unmetabolized form. Enrofloxacin is used in all domestic animal including ruminant and winged animals. In calves, enrofloxacin finds utilization in the respiratory system infections, septicemia caused by colibacillosis and in cases of intestinal inflammation by oral and parenteral ways. There are around 1920 enrofloxacin preparations with different formulations in Turkey. Eight hundred fifty-five of these preparations are in the form of parenteral solutions that are ready for use. In this study, the pharmacokinetics of two enrofloxacin preparations that are used in calves were investigated.

Materials, Methods \& Results: Ten female calves (Jersey strain, 46-50 day-old) were included. The animals were taken to a separate environment 15 days in advance, and medication administration was restrained. Throughout the trial, the animals were fed with unmedicated feed. Calf growing feed, water, and hay were given freely as feed. They continued to be fed by 3 liters of milk twice a day. The study was reviewed by Ankara University Animal Trials Local Ethics Committee and approved with decision number 2007-7-17 and file number 2007-56. The calves were divided into two groups including five calves each. Reference drug and test drug were administered intramuscularly at a dose of $2.5 \mathrm{mg}$ per $\mathrm{kg}$ to group 1 and group 2, respectively. Blood samples were taken before $(0.0 \mathrm{~min})$ and after the drug administration at $0.25,0.5,1,2,4,8$, 12, 18, 24 and 36th $\mathrm{h}$. The method used by Anadon et al. was used for plasma enrofloxacin extraction and concentration. The chemicals, drugs, and solutions that were used in the study are acetonitrile, triethylamine, methanol, enrofloxacin (provided by Bayer Turk), reference drug (50 mg/mL injectable enrofloxacin, $20 \mathrm{~mL}$ per vial), test drug $(100 \mathrm{mg} / \mathrm{mL}$ injectable enrofloxacin, $20 \mathrm{~mL}$ per vial). The pharmacokinetic variables were investigated after parenteral administration of reference and test drugs. The plasma concentration-time curve for each animal showed that enrofloxacin followed the two-compartment open model. There was statically significant differences in area under curve, absorption rate constant and absorption half-life between reference and test drugs $(P<0.05)$. However these differences were evaluated as insignificant from the point of clinical pharmacology. Peak plasma concentration was reached 0.8-1.2 $\mathrm{h}$ after the administration of both reference and test drugs. It was also seen that the drug concentration stayed above $0.5 \mu \mathrm{g} / \mathrm{mL}$ for approximately $4 \mathrm{~h}$ and decreases to $0.04 \mu \mathrm{g} / \mathrm{mL}$ at the 36th hour after administration.

Discussion: The results obtained for both reference and test drugs in this study show that enrofloxacin is well absorbed from the gastrointestinal track. The drug concentration in plasma continues to be higher than $0.5 \mathrm{mg} / \mathrm{mL}$ during the first $24 \mathrm{~h}$. The authors of this study think that the differences that were found in this study regarding pharmacokinetic variables are not significant regarding clinical pharmacology although some statistically significant differences were found. The results of this study imply that both reference and test drugs may be used interchangeably.
\end{abstract}

Keywords: calf, enrofloxacin, pharmacokinetic. 


\section{INTRODUCTION}

Enrofloxacin is a bactericidal antimicrobial drug in the fluoroquinolone group, developed for use only in the veterinary field [4,5,9]. It is effective against gram negative and gram positive bacteria, Mikoplazma, Rickettsia, Ehrlichia and Chlamydia [6,7]. Enrofloxacin is used in all pets, especially in the ruminant and poultry. In calves, enrofloxacin finds utilization in the respiratory system infections, septicemia caused by colibacillosis and in cases of intestinal inflammation by oral and parenteral ways $[3,5,8]$.

The rate and extent of enrofloxacin distribution across tissue barriers are also high. The volume of distribution volume is large and ranges between $0.6-3.0 \mathrm{~L} /$ $\mathrm{kg}$ among animal species. The peak drug concentrations (Cmax) in saliva and bronchial secretion are lower than Cmax in serum. However, Cmax in lung tissue is higher than that in serum [13]. The concentration in the lung may be many times more than the concentration in the plasma in calves and cattle. Enrofloxacin hardy passes into the cerebrospinal fluid [1]. The absorption from the gastrointestinal system in calves and winged animals is above $50 \%$ and $60 \%$, respectively. In calves, the Cmax reaches to $0.9 \mu \mathrm{g} / \mathrm{mL}$ at the 60th min after administration at a dose of $2.5 \mathrm{mg} / \mathrm{kg}$ and continues to be above 0.5 $\mu \mathrm{g} / \mathrm{mL}$ in the first $12 \mathrm{~h}$ period [11]. Enrofloxacin shows similar pharmacokinetic characteristics in cattle.

There are around 1920 enrofloxacin preparations with different formulations in Turkey. Eight hundred fifty-five of these preparations are in the form of parenteral solutions that are ready for use [12]. In this study it were investigated the pharmacokinetics of two enrofloxacin preparations that are used in calves.

\section{MATERIALS \& METHODS}

\section{Chemicals, drugs and solutions}

The chemicals, drugs, and solutions that were used in the study are as follows [12].

Acetonitrile: Gradient Grade for Liquid Chromatograph, Merck 100030 ${ }^{1}$

Triethylamine: Sigma T- $0886^{1}$

Methanol: Gradient Grade for Liquid Chromatograph, Merck $100067^{1}$

Enrofloxacin: Effectiveness, $100.3 \%$; production date: 01,01,2009, Expiry date: 01.01.2011; Serial Number: 176293; Lot 010001160374; Batch KP047PZ ${ }^{2}$
Reference drug: $50 \mathrm{mg} / \mathrm{mL}$ injectable enrofloxacin, $20 \mathrm{~mL}$ per vial, (Baytril-k, 5\%)

Test Drug: $100 \mathrm{mg} / \mathrm{mL}$ injectable enrofloxacin, $20 \mathrm{~mL}$ per vial, (Enrolen, 10\%) $)^{3}$

\section{Trial animals and their care-feeding}

The study was conducted with ten female calves of Jersey race and 46-50 days old (mean 40-45 $\mathrm{kg}$ ) at Karaköy Agricultural Enterprise. The animals were taken to a separate environment 15 days in advance, and medication administration was restrained. Throughout the trial, the animals were fed with unmedicated feed. Calf growing feed, water, and hay were given freely as feed. They continued to be fed by 3 liters of milk twice a day. The study was reviewed by Ankara University Animal Trials Local Ethics Committee and approved with decision number 2007-7-17 and file number 2007-56.

Grouping of the Animals, Administrating the Drugs, Collecting Blood Samples and Drug Analysis in Plasma.

The animals were weighed one day before the drug administration for accurate dosage purposes. The animals were divided into two groups (Group 1 and Group 2) each consisting of 5 animals. Group 1 was assigned to the reference drug group, and Group 2 was assigned to the test drug group. In both groups, the drugs were administered intramuscularly (m.semitendinosus, m.semimembranosus). The dose for all administrations was determined as $2.5 \mathrm{mg} / \mathrm{kg}$. 8-10 mL blood was collected from the animals through $V$. jugularis in vacuumed heparinized tubes before the administration $(0.0 \mathrm{~min})$, and starting at 0.25 th $\mathrm{h}$ following the drug administration at 0.5 th, $1 \mathrm{st}, 2 \mathrm{nd}, 4$ th, 8th, 12th, 18th, 24th and 36th h. Plasmas were stored at $-20^{\circ} \mathrm{C}$ until the drug analyses. The analyses were performed within two months.

Sixty min after collecting the blood samples, the plasma was separated by centrifuge at $704 \mathrm{~g}$ for $10 \mathrm{~min}$. The extraction and sample measurement in enrofloxacin analyses in the plasma was conducted by Düzen Laboratories Group using high pressure liquid chromatography. In the extraction and measurement of enrofloxacin from the plasma, the method used by Anadon et al. was taken as a basis. According to this, $200 \mu \mathrm{L}$ plasma was taken into Eppendorf tubes; 300 $\mu \mathrm{L}$ acetonitrile was added. The tubes were capped and gently vortexed ( $2 \mathrm{~min}$ ). Then, they were centrifuged at $489 \mathrm{~g}$ for $10 \mathrm{~min}$. The acetonitrile part at the top 
was taken into vials with an insulin injector; $300 \mu \mathrm{L}$ deionized water was added and gently vortexed $(0.5$ $\mathrm{min})$. The vials were submitted to high pressure liquid chromatography. The automated sampler was set to $280 \mathrm{~nm}$ wavelength and to use $20 \mu \mathrm{L}$ from this extract. It was submitted to the device for $12 \mathrm{~min}$. The flow rate of the mobile phase was set at $1 \mathrm{~mL} / \mathrm{min}$ and the column temperature as $30^{\circ} \mathrm{C}$. Before the extraction, the retention time, recovery and sensitivity limit were calculated. The standard curves were drawn according to the results obtained.

\section{Pharmacokinetic calculations and statistical calculations}

The calculations for plasma drug concentration distribution phase rate constant ( $\alpha$ lpha), absorption rate constant $(\mathrm{ka})$, alpha half-life $\left(\mathrm{t}^{1} / 2 \alpha\right)$, elimination phase rate constant (beta), beta half-life $\left(t^{1} / 2 \beta\right)$, mean residence time (MRT; the period required for the elimination of $63.2 \%$ of the drug) were made with Pharmacokinetic Calculation (PKCALC) program which is based on the equation reported by Shumaker and Wagner $[16,17]$. For the statistical calculations, the "SPSS 11.0 for Windows" statistics package program $^{3}$ was used. Data were presented as an arithmetic mean \pm standard deviation or the pharmacokinetic data, One-Way Analysis of Variance (ANOVA) was used, and the differences between the groups were evaluated through Duncan test.

\section{RESULTS}

The plasma enrofloxacin concentrations of the reference and test drugs are shown in Table 1. It is shown in the table that Cmax is reached 0.8-1.2 $\mathrm{h}$ after the administration of both reference and test drugs. It is also seen that the drug concentration stays above 0.5 $\mu \mathrm{g} / \mathrm{mL}$ for approximately $4 \mathrm{~h}$ and decreases to 0.04 $\mu \mathrm{g} / \mathrm{mL}$ at the 36 th $\mathrm{h}$ after administration. The differences in pharmacokinetic variables after intramuscular administration of enrofloxacin for reference and test drugs are shown in Table 2.

\section{DISCUSSION}

Enrofloxacin is effective against bacteria that are resistant to antibiotics such as aminoglycosides and tetracyclines. The superiority of enrofloxacin is related with the better tolerability in the gastrointestinal tract, good absorption after gastrointestinal and parenteral administration, good penetrance to tissues including prostate and joint liquids, large distribution volume, good penetrance to intracellular compartment and effect to intracellular bacteria and bactericidal effect at low concentrations $[3,7-10,15]$.

Enrofloxacin is converted to several effective and ineffective metabolites including ciprofloxacin. As much as ten percent or fifty percent of drug is eliminated via urine and bile in unmetabolized form. Enrofloxacin is used in all domestic animal including ruminant and winged animals. It is used in septicemia caused by colibacillosis, intestinal infections and respiratory infections in calves $[3,5,8]$. It is also used in intestinal infections caused by Escherichia coli, Salmonella species and Clostridium perfringens, respiratory infections caused by Pasteurella multocida, Pasteurella haemolytica, Haemophilus somnus, mastitis cases caused by E. coli, Klebsiella pneumoniae, Staphylococcus aureus and eye infections caused by Moraxella bovis [3,5]. The plasma half-life of enrofloxacin in calves is 5-6 h [10].

In this study, it was seen that the distribution of enrofloxacin is fast after the administration and absorption of the drug. The alpha half-life $\left(t^{1} / 2 \alpha\right)$ was found as $2.09 \pm 0.27 \mathrm{~h}$ and $2.29 \pm 0.34 \mathrm{~h}$ for reference and test drugs, respectively. These half-life periods are longer than the half-life results that were found in a study performed by Parlar and Kaya[14] and by Anadon [2]. However, Elmas et al. [6,7] and Kaya et al. [11] found similar results. By using the agar gel diffusion technique, Parlar and Kaya [14] found alpha half-life as $0.14 \pm 0.07 \mathrm{~h}$ and $0.09 \pm 0.01 \mathrm{~h}$ for refer-

Table 1. Plasma drug concentration-time curve after intramuscular administration $(2.5 \mathrm{mg} / \mathrm{kg})$ of enrofloxacin in reference and test drugs.

\begin{tabular}{ccc}
\hline \multirow{2}{*}{ Time $(\mathrm{h})$} & \multicolumn{2}{c}{ Enrofloxacin concentration $(\mu \mathrm{g} / \mathrm{mL})$} \\
\cline { 2 - 3 } & Reference drug & Test drug \\
\hline 0.25 & $0.80 \pm 0.24$ & $0.92 \pm 0.28$ \\
0.5 & $1.01 \pm 0.22$ & $1.22 \pm 0.37$ \\
1 & $1.10 \pm 0.22$ & $1,614 \pm 0.43$ \\
2 & $0.80 \pm 0.21$ & $1.56 \pm 0.28$ \\
4 & $0.58 \pm 0.26$ & $0.93 \pm 0.42$ \\
8 & $0.16 \pm 0.09$ & $0.33 \pm 0.11$ \\
12 & $0.08 \pm 0.04$ & $0.14 \pm 0.04$ \\
18 & $0.05 \pm 0.01$ & $0.07 \pm 0.02$ \\
24 & $0.04 \pm 0.00$ & $0.05 \pm 0.01$ \\
36 & $0.04 \pm 0.00$ & $0.04 \pm 0.00$ \\
\hline
\end{tabular}

All the differences between reference and test drug were statistically insignificant $(P<0.05)$. 
Table 2. Some pharmacokinetic variables of reference and test drug.

\begin{tabular}{|c|c|c|}
\hline Variable & $\begin{array}{c}\text { Reference Drug } \\
\text { Mean } \pm \text { SD }\end{array}$ & $\begin{array}{c}\text { Test Drug } \\
\text { Mean } \pm \text { S D }\end{array}$ \\
\hline Area under curve ( $\mu \mathrm{g}$, hour/L) & $6.54 \pm 0.69^{\mathrm{a}}$ & $10.33 \pm 0.89^{\mathrm{b}}$ \\
\hline Mean retention time $(\mathrm{h})$ & $17.05 \pm 2.23$ & $24.71 \pm 14.19$ \\
\hline Distribution phase rate constant (alpha, hour ${ }^{-1}$ ) & $0.35 \pm 0.05$ & $0.32 \pm 0.04$ \\
\hline Elimination phase rate constant (beta, hour ${ }^{-1}$ ) & $0.03 \pm 0.01$ & $0.13 \pm 0.88$ \\
\hline Absorption rate constant $\left(\mathrm{ka}\right.$, hour $\left.^{-1}\right)$ & $4.01 \pm 0.66^{\mathrm{a}}$ & $1.80 \pm 0.23^{\mathrm{b}}$ \\
\hline Alpha Half-life ( $\mathrm{t}^{1} / 2 \alpha$, hour $)$ & $2.09 \pm 0.27^{\mathrm{a}}$ & $2.29 \pm 0.34^{\mathrm{b}}$ \\
\hline Beta Half-Life ( $\mathrm{t}^{1} / 2 \beta$, hour) & $21.25 \pm 3.80$ & $30.83 \pm 15.15$ \\
\hline Absorption half-life ( $t^{1} / 2 a$, hour) & $0.01 \pm 0.03$ & $0.40 \pm 0.04$ \\
\hline Tmax (hour) & $1.00 \pm 0.27$ & $1.20 \pm 0.20$ \\
\hline $\operatorname{Cmax}(\mu \mathrm{g} / \mathrm{mL})$ & $1.12 \pm 0.10$ & $1.66 \pm 0.15$ \\
\hline
\end{tabular}

SD: standard deviation, Min-Max: Minimum-Maximum; Different letters in the same rows (a, b) are statistically significant $(P<0.05)$.

ence and test drugs, respectively, after administration of the drug via drinking water. Anadon et al. found alpha half-life as $1.43 \pm 0.10 \mathrm{~h}$ via craw administration and as $0.07 \pm 0.01 \mathrm{~h}$ via intravascular administration [2]. Elmas et al. [6,7] found alpha half-lives as 2.37 $\pm 0.25 \mathrm{~h}$ and $0.62 \pm 0.13 \mathrm{~h}$ via oral and intravascular administration from the same group. The authors also found that alpha half-lives were $1.48 \pm 0.47 \mathrm{~h}$ and $1.7 \pm$ $0.43 \mathrm{~h}$ via oral and intramuscular injection with HPLC technique [6,7]. By using agar gel diffusion technique, Kaya et al. found alpha half-lives as $0.24 \pm 0.03 \mathrm{~h}$ via intravascular administration, $2.09 \pm 0.75$ and $3.97 \pm$ $1.40 \mathrm{~h}$ for two test drugs via craw administration [11].

In this study, the elimination phase half-life $\left(\mathrm{t}^{1} / 2 \beta\right)$ of enrofloxacin was found as $21.25 \pm 3.80 \mathrm{~h}$ and $30.83 \pm$ $15.15 \mathrm{~h}$ for the reference and test drugs, respectively. These values are higher than those found by Anadon et al. [1] and Elmas et al. [7] but lower than that found by Parlar and Kaya [14] and Kaya et al. [11] By using agar gel diffusion technique, Anadon et al. [1] found $\mathrm{t}^{\mathrm{t}} / 2 \beta$ as $2.5-3.0 \mathrm{~h}$ after administration of the drug by drinking water. The same author found $\mathrm{t}^{\mathrm{t}} \mathrm{2} \beta$ as $14.23 \pm 0.46 \mathrm{~h}$ by using high-pressure liquid chromatography after administration via craw. [1] By using high-pressure liquid chromatography, Elmas et al. [7] found $\mathrm{t}^{\mathrm{t}} / 2 \beta$ values as $9.26 \pm 0.65$ and $8.15 \pm 0.18 \mathrm{~h}$ via oral administration and $4.70 \pm 0.44 \mathrm{~h}$ via intramuscular injection [6,7]. By using agar gel diffusion technique, Parlar and Kaya [14] found $t / 2 \beta$ values as $17.32 \pm 1.69 \mathrm{~h}$ for reference drug and $5.33 \pm 0.21$ and $34.65 \pm 2.72 \mathrm{~h}$ for test drugs after administration via drinking water. Kaya et al. [11] found $14.82 \pm 4.67 \mathrm{~h}$ for reference drug and $26.38 \pm$ $11.64 \mathrm{~h}$ for test drug by using agar gel diffusion technique.
In this study, distribution phase rate constant (alpha) showed the low duration of distribution phase. Alpha value was found as $0.35 \pm 0.05$ and $0.32 \pm 0.04$ $\mathrm{h}^{-1}$ for reference and test drugs, respectively. The difference was statistically insignificant.

In this study, Tmax was $1.00 \pm 0.27 \mathrm{~h}$ for reference drug and $1.20 \pm 0.20 \mathrm{~h}$ for test drug. These values are similar to those that were found by Elmas et al. $1.09 \pm 0.28 \mathrm{~h}$ ) by using high-pressure liquid chromatography via intramuscular administration. Cmax was $1.12 \pm 0.10 \mu \mathrm{g} / \mathrm{mL}$ for reference drug and $1.66 \pm 0.154$ $\mu \mathrm{g} / \mathrm{mL}$ for test drug. These Cmax values are similar to that found by Posniak et al. [15] [high pressure liquid chromatography and craw administration $(0.92 \pm 1.10$ $\mu \mathrm{g} / \mathrm{mL}$ and $0.98 \pm 0.10 \mu \mathrm{g} / \mathrm{mL}$ for reference and test drugs, respectively)] and by Anadon et al. [1] (agar gel diffusion technique, administration via drinking water, $1.40 \mu \mathrm{g} / \mathrm{mL})$. However, Elmas et al. [6] found higher values $(3.25 \pm 0.29 \mu \mathrm{g} / \mathrm{mL})$ via intramuscular injection and high pressure liquid chromatography technique.

The results obtained for both reference and test drugs in this study show that enrofloxacin is well absorbed from the gastrointestinal track. The drug concentration in plasma continues to be higher than $0.5 \mathrm{mg} / \mathrm{mL}$ during the first $24 \mathrm{~h}$.

\section{CONCLUSIONS}

We think that the differences that were found in this study regarding pharmacokinetic variables are not significant regarding clinical pharmacology although some statistically significant differences were found. The results show that reference and test drugs are not similar. Test drug is absorbed better than reference drug and may be used interchangeably with reference drug. 


\section{MANUFACTURERS}

${ }^{1}$ Merck, İlaç Ecza ve Kimya Tic.A.Ş. Istanbul, Turkey.

${ }^{2}$ Bayer Türk Kimya San. Ltd. Şti. Istanbul, Turkey.

${ }^{3}$ Alke Sağlık Ürünleri. Istanbul, Turkey.

Declaration of interest. The authors report no conflicts of interest. The authors alone are responsible for the content and writing of paper.

Ethical approval. The study was approved by the ethical board of Ankara University Veterinary Faculty (Approval Number: 2007/56).

\section{REFERENCES}

1 Beserra H.E. 2016. Linfonodo sentinela. In: Daleck C.R. \& de Dardi A.B. (Eds). Oncologia em cães e gatos. São Paulo: Roca, pp.128-132.

2 Branco A.W. \& Kondo W. 2007. Linfadenectomia por vídeo-laparoscopia no câncer de próstata. Revista brasileira de videocirurgia. 5(3): 121-127.

3 Brenet O., Lalourcey L. \& Queinnec M. 2013. Hypersensitivity reactions to patent blue v in breast cancer surgery: a prospective multicentre study. Acta Anesthesiology Scandinava. 57(1): 106-117.

4 Castelo D., Figueiredo A. Parada B., Nunes P. \& Mota A. 2010. O papel da linfadenectomia pélvica nos doentes submetidos a prostatectomia radical. Acta urológica. (4): 17-27.

5 Cowell R.L., Dorsey K.E. \& Meinkoth J.H. 2003. Lymph node cytology. Veterinary Clinical North American Small Animal Practice. 33(1): 47-67.

6 de Nardi A.B., Ferreira T.M.M.R. \& Assunção K.A. 2016. Neoplasias mamárias. In: Daleck C.R. \& de Nardi A.B. (Eds). Oncologia em cães e gatos. São Paulo: Roca, pp. 498-516.

7 Jeudy G. Louvier N., Rapennes T., Goujon E., Fraisse J., Dalac-Rat S. \& Collet E. 2008. Immediate patent blueinduced hypersensitivity during sentinel node detection: the value of cutaneous tests. Annales de Dermatologie et de Vénéréologie. 135(6): 461-465.

8 Justino R.C., Cardoso G.S., Trautwein L.G.C., Dessunti G.T., Oliveira D.V., Bernardes R. \& Martins M.I.M. 2014. Uterine lymphangiography: comparison of two methods for locating the medial iliac lymph node. Pesquisa Veterinária Brasileira. 34(11): 1121-1126.

9 Karayannopoulou M., Kaldrymidou E., Constantinidis T.C. \& Dessiris A. 2005. Histological grading and prognosis in dogs with mammary carcinomas: application of a human grading method. Journal of Comparative Pathology. 133(4): 246-252.

10 Maranhão M.V.M., Nóbrega D.K.A, Anunciação C.E.C., Maia B.A.B. \& Mariano P.V.D. 2016. Allergic reaction to patent blue dye in breast surgery - case report. Brazilian Journal of Anesthesiology. 66(4): 433-436.

11 Miyashiro I., Kishi K., Yano M., Tanaka K., Motoori M., Ohue M., Ohigashi H., Takenaka A., Tomita Y. \& Ishikawa O. 2011. Laparoscopic detection of sentinel node in gastric cancer surgery by indocyanine green fluorescence imaging. Surgical Endoscopy. 25(5): 1672-1676.

12 Patsikas M.N., Karayannopoulou M., Kaldrymidoy E., Papazoglou L.G., Papadopoulou P.L., Tzegas S.I., Tziris N.E., Kaitzis D.G., Dimitriadis A.S. \& Dessiris A.K. 2006. The lymph drainage of the neoplastic mammary glands in the bitch: a lymphographic study. Anatomia, histologia e embryologia. 35(4): 228-234.

13 Pereira C.T., Rahal S.C., de Carvalho Balieiro J.C. \& Ribeiro A.A. 2003. Lymphatic drainage on healthy and neoplasic mammary glands in female dogs: can it really be altered? Anatomia, histologia, embryologia. 32(5): 282-290.

14 Pinheiro L.G.P., Moraes M.O., Soares A.H., Lopes A.J.T., Naguére M.A.S.P., Gondim F.A.L., Brandão C.B., Nascimento D.C.H., Soares J.P.H. \& Silva J.M.M. 2003. Estudo experimental de linfonodo sentinela na mama da cadela com azul patente e tecnécio tc99. Acta Cirúrgica Brasileira. 18(6): 545-552.

15 Pinheiro L.G.P., Oliveira Filho R.S., Vasques P.H.D., Filgueira P.H.O., Aragão D.H.P., Barbosa P.M.E., Beserra H.E.O. \& Cavalcante R.V. 2009. Hemosiderin. A new marker for sentinel lymph node identification. Acta Cirúrgica Brasileira. 24(6): 432-436.

16Suga K., Karino Y., Fujita T., Okada M., Kawakami Y., Ueda K., Yuan Y. \& Matsunaga N. 2007. Cutaneous drainage lymphatic map with interstitial multidetector-row computed tomographic lymphography using iopamidol: preliminary results. Lymphology. 40(2): 63-73.

17 Wainstein A.J.A., Barbosa L.C.C.S., Kansaon M., Salomé M. \& Drummond-Lage A.P. 2015. Advanced malignant melanoma during pregnancy: technical description of sentinel lymph node biopsy followed by radical lymph node dissection. Revista Brasileira de Saúde Materna Infantil. 15(4): 447-450. 
G.B.Ç. Bideci \& S. Kaya. 2018. The Investigation of the Pharmacokinetics of Two Enrofloxacin Preparations Following Parenteral Administration in Calves. Acta Scientiae Veterinariae. 46: 1543.

18 Wells S., Bennett A., Walsh P., Owens S. \& Peauroi J. 2006. Clinical usefulness of intradermal fluorescein and patent blue violet dyes for sentinel lymph node identification in dogs. Veterinary and Comparative Oncology. 4(2): 114-122. 